\title{
Implementation of a Coupon System in Municipalities and Its Significance in Area of Waste Sorting as Green Economy
}

\author{
Katarína Teplická ${ }^{*}$, Jaroslava Kádárová ${ }^{2}$, Martin Kováčç \\ ${ }^{1}$ Technical University, Faculty BERG, Park Komenského19, Kosice, Slovakia \\ ${ }^{2}$ Technical University, Faculty of Mechanical Engineering, Park Komenského 9, Košice, Slovakia \\ ${ }^{3}$ Technical University, Faculty of Civil Engineering, Vysokoškolská 4, Košice, Slovakia
}

Received: 23 November 2020

Accepted: 6 February 2021

\begin{abstract}
This paper summarizes the arguments within the scientific discussion on the issue of reducing municipal waste in municipalities in Slovakia. The aim of the paper is to examine the environmental and economic impacts of waste management in municipalities in Slovakia and to determine the impact of the introduction of a coupon system in the field of municipal waste sorting in municipalities. Methods of research were focused on using statistical indicators for the valuation of municipal waste, cluster analysis, regression analysis, and comparison analysis. The object of research were chosen 8 municipalities in Slovakia that implemented coupon system of waste sorting. The research empirically confirms and theoretically proves that the development trend of municipal and separated waste has a linear progressive course that means increasing of municipal waste and separated waste. The indicator RSquare indicates that the number of inhabitants affects the generation of municipal waste at $67,03 \%$. Defined three clusters can be a tool for the classification of municipalities in the sorting of municipal waste after the implementation of a coupon system. The results of the research can be useful for legislative changes in Waste Law in Slovakia and opportunities for law changes in municipalities in the EU.
\end{abstract}

Keywords: waste, coupon system, environmental costs, efficiency, separating

\section{Introduction}

The biggest environmental challenges in Slovakia within the environmental policy 2030 are the issues

*e-mail: katarina.teplicka@tuke.sk of waste management, air quality, and habitat protection [1]. The problem of waste management in municipalities is a priority strategic task today. The European Union deals with these mentioned aspects, trying to maintain long-term competitiveness and to provide sustainable development in accordance with all related environmental aspects [2]. The vision of Enviro 
strategy 2030 is to achieve a higher quality of the environment with a focus on increasing the recycling rate of municipal waste to $60 \%$ and reducing the landfill rate to $25 \%$ [3]. Generally, within global waste management initiatives, the main goal is to minimize the negative effects of waste on the environment, as well as to increase and optimize the sources' efficiency in the waste economy [4-6]. The aim of the paper is to examine the environmental and economic impacts of waste management in municipalities in Slovakia and to determine the impact of the introduction of a coupon system in the field of municipal waste sorting in municipalities. The motivating factor in municipalities could be $100 \%$ separation of waste, which would reduce fees for citizens and at the same time the expenses of the municipality associated with waste management.

\section{Waste Economy in Municipalities}

As a result of urbanization and economic prosperity, which has accelerated the generation of municipal solid waste (MSW) along with its organic fraction, the management of MSW is a challenge faced by urban centers worldwide, including the European Union (EU) and Canada. Within a concept of waste recovery, the source separation and on-site treatment of urban organic waste (UOW) can resolve some of the major economic issues faced by urban centers along with the environmental and social issues associated with landfilling [7]. Andhikari et.al. (2010) dealt with composting strategies using a combination of centralized composting facilities, community composting centers and home composting [8]. Municipal mayors are looking for new alternative solutions to reduce the amount of municipal waste and how to motivate municipal residents to sort municipal waste [9]. Bumley (2007) dealt with the composition of municipal solid waste in UK in municipalities. The results of surveys show information of the composition of households-collected waste. Composition of waste depends on the size, age profile of households, of size of waste container, of socio-economic state of households, of possibilities for waste separating in municipalities [10]. Those factors mean motivation factors for the improvement of waste separating. Today, the municipality is obliged to create conditions for waste separation in the municipality by a suitable system. The reason for waste sorting is saving natural resources - raw materials and energy, reducing the amount of waste in landfills, eliminating black landfills, reusing waste by recycling [11]. By sorting waste, we help the environment, thereby reducing the adverse effects of human exposure on the environment. The form of effective sorting of municipal waste depends on the representatives of the municipality and citizens. The search for motivational factors on how to inspire the inhabitants of towns and municipalities to sort municipal waste is a strategic goal of waste management of towns and municipalities, because they pay for municipal waste from their own budgets. Bel et.al. (2015) dealt with cost-saving reforms in local government. Cost savings is base of reforms in municipalities. Cost saving is building on inter-municipal cooperation, that is dependent on the cost structure of public services, the structure of local government, and the governance framework at the local/regional level. Costs related to waste management include collection, transport, storage and sorting of waste. The amount of the fee for the collection of municipal waste is set by the municipality in a generally binding regulation according to the amount of costs for the collection of municipal waste through service providers [12]. Boonrod et.al. (2015) they dealt with organic waste separation behavior when various motivation mechanisms are implemented in area of separation. A traditional mechanism was introduced as a voluntary mechanism of waste separation by household composting, second mechanism is economical, a reward mechanism according to the amount of separated waste, the third mechanism is business mechanism for using organic waste for energy projects [13]. Hwang et.al. 2020 they dealt with co-composting of organic wastes is globally recognized to be an effective method to dispose two or more wastes at once and minimize drawbacks of composting such as gases emissions and nutrient reduction. Pilot-scale experiments were conducted to characterize the co-composting process of chicken manure with cow manure (CC), swine manure (CS), plant residues plus mushroom media (CRM), on emissions of greenhouse gas, and ammonia, compost quality, maturity and their correlations. The results showed importance of selection for co-composting material [14]. Waste sorting is very important from an environmental, economic and social point of view. Sorting individual types of waste in households is the first step in the field of municipal waste management, while the motivating factor is education by municipal representatives and awareness of citizens.

Separate collection makes it possible to return secondary raw materials to the production process. The extraction and extraction of primary raw materials is being reduced. Based on this approach, it is possible not to devastate the territory of the country due to mining, reduce mining and extraction of primary raw materials, reduce the amount of energy consumed, pollute the environment to a lesser extent due to non-construction of landfills and incinerators, negatively affect transport air, processing of raw materials, contaminating arable land with chemical fertilizers. Waste separation rates also increased-mainly based on the legislative support in Slovakia. Brauweiler et.al. (2017) they dealt with current problems of waste management in Ukraine. The Essence of economic and legal mechanisms of waste management is defined by the law. One of the alternative solution of waste management are legal norms provides the improvement [15]. Bucciol et.al. (2015) they examined combining of non-monetary and monetary incentives increases municipal solid 
waste sorting in Italy. Mechanism of system DtD (door-to-door) has economic, environmental, social benefits and it reinforces motivation of households for waste separating [16]. Buenrostro et.al. (2001) they dealt with classification of municipal solid waste (MSW) in municipalities. This classification creates connection between the sourer and the type of waste. The classification categorizes the sources into three divisions and seven classes of sources: residential, commercial, institutional, construction/demolition, agricultural-animal husbandry, industrial, and special. This classification is an instrument for planning waste separating system in municipalities [17]. Bareková et.al. (2020) solved waste separating. The municipalities in Slovakia have a duty to separate biodegradable municipal waste from family houses. This duty can be achieved by home composting or by collection of green waste in bio-bins, which are regularly emptied by a collection company. The conducted research confirmed the urban population has a lower rate of compostable kitchen waste compared to the residents in villages [18]. Gardiner, Hajek (2020) solved by panel model that it exists the relationship between economic growth and waste generation. They obtained that traditional economic development policies are not enough to reduce waste generation in EU regions. They suggest economic tools, such as charges and incentives, and eco-innovation policies should be introduced to promote the region's shift towards a circular economy model [19]. Toninin et.al. (2020) comment that food waste represents the largest fraction of the municipal solid waste generated in Europe and its management is associated to suboptimal performance in environmental, health, and social dimensions. Possibility alternatives involve separate collection of food waste followed by biological treatments (home/ centralized composting and anaerobic digestion), centralized mechanical-biological treatment followed by anaerobic digestion [20]. Araiza et. al. (2020), they dealt with a forecast model to determine the rate of generation of municipal solid waste in the municipalities of the Cuenca del Canon del Sumidero, Chiapas, Mexico. The most important variables to predict the rate of waste generation in the study area were the population of each municipality, the migration and the population density [21]. Coupon system is an important instrument for policy of waste management of municipalities in Slovakia [22]. The volume of generated municipal waste increases proportionally with the rise in population and higher personal consumption. Municipal waste management requires considerable financial resources. The average fee for municipal waste and minor construction waste is gradually increasing. The fee amount depends on where is paid (municipality or city), its population count, the region in which the municipality is situated, on the company, that waste collection [23]. A coupon system is one of the alternatives that are motivating factors for waste separation in municipalities.

\section{Material and Methods - Experimental Procedures}

We chose the methodological procedure in this paper in several steps (Fig. 1). The basic tool for processing analyzes was the Waste Law 79/2015 and the website of the Ministry of the Environment.

In addition to data collection, we also used economic and statistical analysis through the JMP SAS software approach in the preparation of reports. At the same time, we used data from the websites of individual selected municipalities. This methodological approach allowed us to quickly process the collected data, evaluate the results of the established coupon system in selected municipalities and determine conclusions suitable for implementation in municipalities throughout Slovakia. In the research of the coupon system of waste sorting in municipalities in Slovakia, we proceeded according to the following steps.

\section{Analysis of the Current State of the Coupon System}

In the first step of the research, we found out which municipalities have an implemented coupon system for sorting municipal waste in the form of personal telephone conversations, by monitoring the websites of municipalities, by interviewing mayors of municipalities.

\section{Municipal Waste Data Collection in Selected Municipalities with Coupon System}

In the second step of the research, we found out data of municipal waste and separated waste in selected municipalities from database e-obce.sk, from reports of municipalities about state of waste, that have be

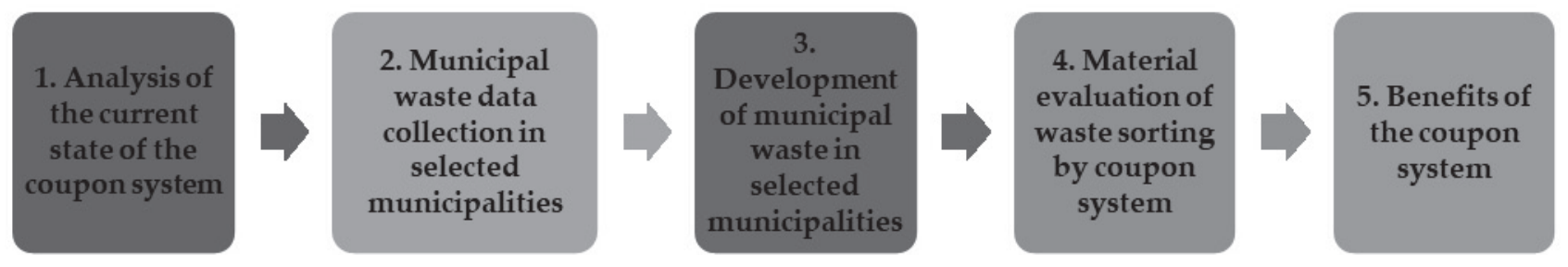

Fig. 1. Algorithm of research in municipalities in Slovakia. 
presented on the municipalities web sides, from the internal documents of municipalities.

\section{Development of Municipal Waste in Selected Municipalities with Coupon System}

In the third step of the research, we analysed development of municipal waste through compare analyse and by statistical indicators. We used indicators how average of municipality waste per capita, absolute difference, index of municipality waste during period three years 2017-2019.

Average of municipality waste per capita:

$$
A=\frac{Q m w}{n}
$$

Qmw- quantity of municipal waste in $(\mathrm{kg})$, $\mathrm{n}$ - number of people in municipality.

Absolute difference of municipality waste:

$$
A D=X i-X \mathrm{i}-1
$$

$\mathrm{Xi}$ - municipality waste in the current period, $\mathrm{Xi}-1$ - municipality waste in the base period.

Index of municipality waste:

$$
I=\frac{Q 1}{Q 0}
$$

Q1 - the total quantity of waste in the current period (1), Q0 - the total quantity of waste in the base period (0), immediately preceding period.

\section{Material Evaluation of Waste Sorting by Coupon System}

In the fourth step, we determined the rate of separated waste within municipal waste on the basis of the structure indicator. This indicator monitors the material recovery of waste. Based on the regression analysis, we monitored the impact of the population of municipalities on the generation and amount of municipal waste, and on the basis of cluster analysis, we determined clusters for waste sorting for municipalities.

Structure of separated waste:

$$
S=\frac{Q s w}{Q m w} \times 100 \%
$$

Q sw- quantity of separated waste,

Q mw- quantity of municipal waste.

\section{Benefits of the Coupon System in Municipalities}

In the fifth step of the research, we evaluated the benefits of municipal waste separation based on a comparative analysis. We compared municipal waste, separated waste per person in selected municipalities with an average value per person for Slovakia.

\section{Results}

We will present the research results according to the research algorithm in five steps. The coupon system of municipal waste management is one of the possibilities to reduce municipal waste in municipalities and reduce municipal costs for municipal waste. The main goal of this paper was to present the economic and environmental aspects of the implementation of coupon system. This approach presents the situation that the more a citizen sorts waste, the more he saves on municipal waste fees. At the same time, the municipality will reduce its costs and the amount of waste for which the municipality is responsible in terms of extended producer responsibility in law. This method appears to be an incentive method for waste sorting and recycling in the future in the municipalities in Slovakia.

\section{Analysis of the Current State of the Coupon System}

In the first step of the research, we found out which municipalities have an implemented coupon system for sorting municipal waste in Slovakia (Fig. 2). Municipalities that have coupon system are in the middle region of Slovakia and one municipality Dedinky in east region of Slovakia. We can comment that very little municipalities have this coupon system in Slovakia because it is one alternative solution for municipalities in area of sorting waste and it is not in waste law as a duty.

The waste sorting system - coupon system is focused on sorting waste components. Citizens dispose of municipal waste by purchasing a magnet - a coupon for the value of (€/110 l) container (Fig. 3). Citizens can purchase a magnet at the municipal office.

The amount of magnets that citizens buy is not limited or precisely determined and it depends on the generation of municipal waste of individual households. At the beginning of the introduction of this system, citizens bought more pieces of magnets, but by gradual separation they found out how many magnets they needed and also found out the cycle of collecting municipal waste of their own household. When it is necessary to buy magnets to dispose of municipal waste, they gradually found out and adapted to the plan drawn up by the mayor. Citizens who attach the magnet to the municipal waste container at the planned collection date, the container will be emptied by a company that the municipality has contracted for the collection of municipal waste. For those citizens who do not attach the magnet to the container, the waste collection company will not empty the container. This system motivates citizens to separate the waste and fill the container and only after its full filling to attach 


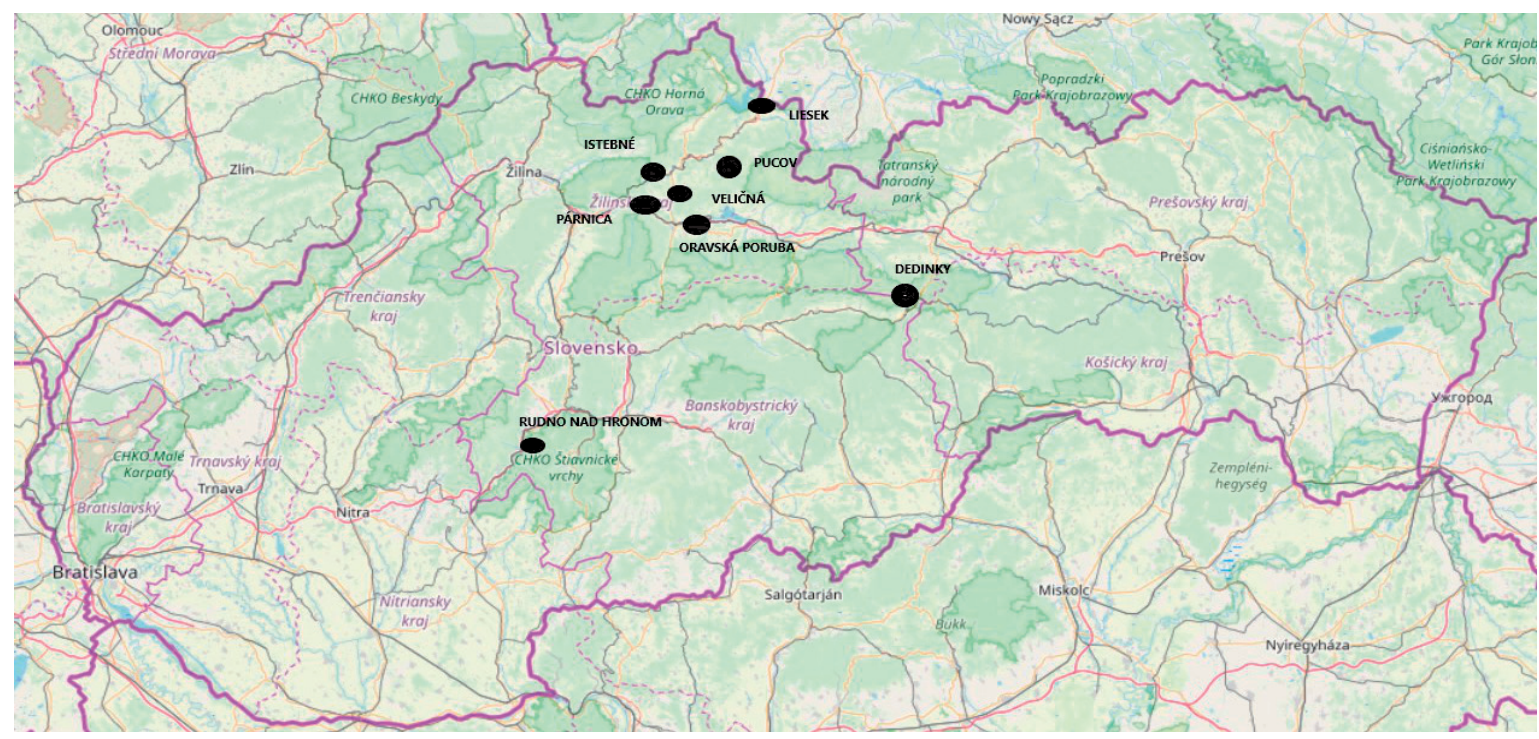

Fig. 2. Municipalities with coupon system in Slovakia [22].

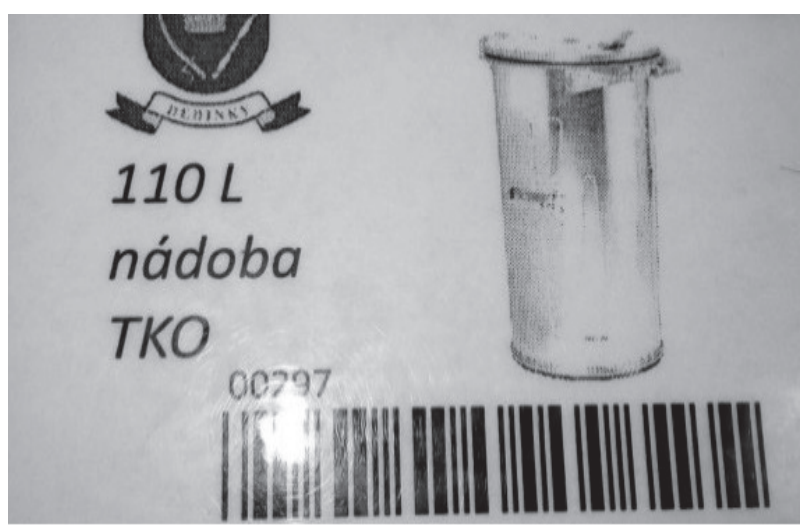

Fig. 3. Coupon - magnet code for coupon system in municipalities in Slovakia.

a magnet for waste collection. This instrument is very important motivation factor for waste separation.

\section{Municipal Waste Data Collection in Selected Municipalities with Coupon System}

In the second step of the research, we found out data of municipal waste and separated waste in selected municipalities (Tables 1, 2). The monitored period was from 2017-2019, when the selected municipalities already had a coupon system in place.

Municipal waste and separated waste in selected municipalities presented all waste in municipality with influence of number of people in municipalities (Table 3).

Municipalities are obliged to report information on waste to the Producer Responsibility Organization for packaging. High levels of environmental pollution and ever-increasing "black dumps" in municipalities are forcing to change their approach to waste management. The amendment to the Waste Act changes the rules for reporting black dumps. From 2019, municipalities must ensure the introduction and implementation of separate

Table 1 . Municipality waste in $(\mathrm{kg})$.

\begin{tabular}{|c|c|c|c|}
\hline Municipality & 2017 & 2018 & 2019 \\
\hline Dedinky & 95590.60 & 40590.20 & 82267.60 \\
\hline Rudno nad Hronom & 91719.63 & 88023.80 & 175646.40 \\
\hline Pucov & 166229.40 & 165747.80 & 275173.20 \\
\hline Párnica & 214846.08 & 268477.14 & 151241.14 \\
\hline Oravská Poruba & 186815.60 & 197474.30 & 183706.60 \\
\hline Veličná & 196042.00 & 171855.00 & 301648.00 \\
\hline Istebné & 284389.60 & 197474.30 & 350832.20 \\
\hline Liesek & 263683.20 & 297340.50 & \\
\hline
\end{tabular}

Source: internal documents of municipalities 
Table 2. Separated waste in $(\mathrm{kg})$.

\begin{tabular}{|c|c|c|c|}
\hline Municipality & 2017 & 2018 & 2019 \\
\hline Dedinky & 12951.90 & 8523.90 & 16467.24 \\
\hline Rudno nad Hronom & 11151.00 & 11682.00 & 83420.00 \\
\hline Pucov & 91160.00 & 81700.00 & 86718.00 \\
\hline Párnica & 36654.00 & 74202.00 & 53346.00 \\
\hline Oravská Poruba & 42886.00 & 54392.00 & 68742.00 \\
\hline Veličná & 57285.00 & 49647.00 & 70720.00 \\
\hline Istebné & 44880.00 & 50620.00 & 142296.00 \\
\hline Liesek & 66792.00 & 113256.00 & \\
\hline
\end{tabular}

Source: internal documents of municipalities

collection of municipal waste for paper, plastics, metals, glass and cardboard-based composite materials. The aim of the change in the law is primarily to increase the share of waste sorting by $50 \%$ to 2020 and by $60 \%$ to 2030 according strategy of EU. There are also significant changes in the Act on Fees for Landfilling Waste [7].

\section{Development of Municipal Waste in Selected Municipalities with Coupon System}

In the third step of the research, we analysed development of municipal waste through comparative analysis and by statistical indicators by formula 1,2 , 3. In selected 8 municipalities in the monitored period 2017-2019 (Fig. 4), municipal waste is growing despite the fact that municipalities have introduced a coupon system for municipal waste treatment.

In the villages, Dedinky, Rudno nad Hronom, Oravská Poruba, Veličná the total amount of municipal waste decreased in the last year 2019. We recorded a significant increase in municipal waste in the villages, Istebné, Liesek, Párnica, Pucov. The development

Table 3. Number of population in municipalities with coupon system.

\begin{tabular}{|c|c|}
\hline Municipality & Population \\
\hline Dedinky & 246 \\
\hline Rudno nad Hronom & 531 \\
\hline Pucov & 860 \\
\hline Párnica & 894 \\
\hline Oravská Poruba & 1046 \\
\hline Veličná & 1273 \\
\hline Istebné & 1360 \\
\hline Liesek & 2904 \\
\hline
\end{tabular}

Source: internal documents of municipalities of the amount of municipal waste has a growing tendency and therefore it is important to address the separation of waste in municipalities. The search for motivational factors on how to inspire the inhabitants of municipalities to sort municipal waste is a strategic goal of waste management of municipalities, because they pay for municipal waste from their own budgets.

Based on statistical analysis (Table 4) of data on municipal waste in municipalities, we can present the following research results.

The share of the amount of municipal waste per 1 person in municipalities is at the level of $90.8 \mathrm{~kg}$ to $388.6 \mathrm{~kg}$ per person. These data represent a value lower than in the EU where the average per person is $487 \mathrm{~kg}$. The share of municipal waste per person is too large and the strategic vision of municipalities is to reduce the share of municipal waste per person. The absolute difference points to the growth and decrease of municipal waste in municipalities. Significant growth was recorded in the municipality Istebné at level $104,173 \mathrm{~kg}$. A significant decrease was recorded in the municipality Istebné at level 86,916 kg, Oravská Poruba at level 46,000 kg, Dedinky at level 55,000 kg. The municipal waste index points mainly to the growth and

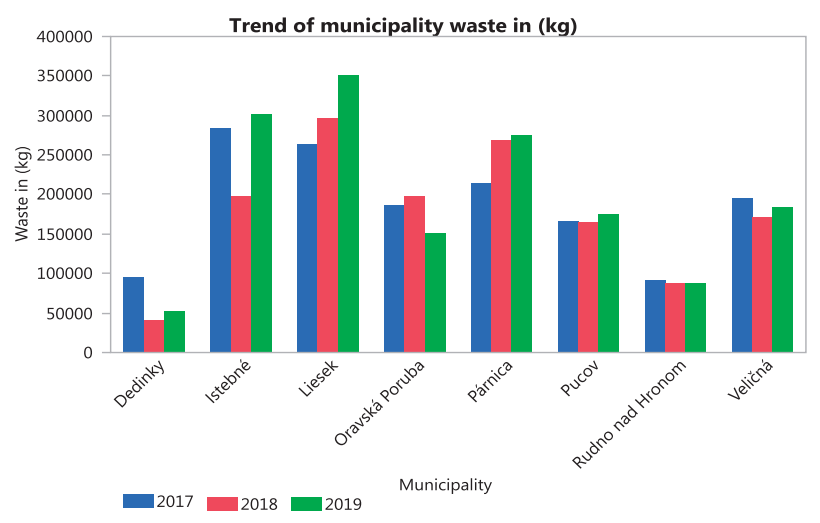

Fig. 4. Trend of development of municipality waste in 8 municipalities in Slovakia 
Table 4. Statistical analysis of municipal waste.

\begin{tabular}{|c|c|c|c|c|c|c|c|}
\hline Municipality & $\mathrm{A} / 2017$ & $\mathrm{~A} / 2018$ & $\mathrm{~A} / 2019$ & $\mathrm{AD} 19 / 18$ & $\mathrm{AD} 18 / 17$ & $\mathrm{I} 19 / 18$ & $\mathrm{I} 18 / 17$ \\
\hline Dedinky & 388.6 & 165.0 & 212.5 & 11677.40 & -55000.40 & 1.3 & 0.4 \\
\hline Rudno nad Hronom & 172.7 & 165.8 & 166.2 & 233.70 & -3695.83 & 1.0 & 1.0 \\
\hline Pucov & 193.3 & 192.7 & 204.2 & 9898.60 & -481.60 & 1.1 & 1.0 \\
\hline Párnica & 240.3 & 300.3 & 307.8 & 6696.06 & 53631.06 & 1.0 & 1.2 \\
\hline Oravská Poruba & 178.6 & 188.8 & 144.6 & -46233.16 & 10658.70 & 0.8 & 1.1 \\
\hline Veličná & 154.0 & 135.0 & 144.3 & 11851.60 & -24187.00 & 1.1 & 0.9 \\
\hline Istebné & 209.1 & 145.2 & 221.8 & 104173.70 & -86915.30 & 1.5 & 0.7 \\
\hline Liesek & 90.8 & 102.4 & 120.8 & 53491.70 & 33657.30 & 1.2 & 1.1 \\
\hline
\end{tabular}

Source: own study

decrease of municipal waste. The highest decrease in selected municipalities was recorded in the municipality Dedinky by $60 \%$ in the year 2018 .

Based on statistical analysis (Table 5) of data on separated waste in municipalities, we can present the following research results.

The share of the amount of separated waste per 1 person in municipalities is at the level of 21-106 $\mathrm{kg}$. The absolute difference points to the growth and decrease of separated waste in municipalities. Economic benefit for separated waste is only the growth and to increase quantity of separated waste in municipalities. Coupon system must to motivate a people to sort waste. A significant increasing of separated waste was recorded at level $46464 \mathrm{~kg}$ in Liesek in year 2018, $37548 \mathrm{~kg}$ in Párnica and $29040 \mathrm{~kg}$ in Liesek in year 2019. Decreasing was recorded in the municipality Dedinky, Pucov, Oravská Poruba, Veličná. The index of separated waste points mainly to the growth and decrease of separated waste by coefficient. The highest growth of separated waste was recorded in the municipality Dedinky by $90 \%$, Párnica $100 \%$. Decreasing of separated waste was recorded between year 2017-2018 at the level $10-30 \%$. On average, it can be stated that the share of separated waste in municipalities has increased, which was the intention of the established coupon system for sorting municipal waste. The value of separated waste in the years 2017-2019 was at the level of minimum $8524 \mathrm{~kg}$ to the maximum $142296 \mathrm{~kg}$. It means that the inhabitants of the municipalities have started sorting waste very good. The value of separated waste has been increasing, which means a positive effect from the established coupon system for waste sorting in selected municipalities.

\section{Material Evaluation of Waste Sorting by Coupon System}

In the fourth step (Table 6), we determined the structure of separated waste of municipal waste on the basis of the structure indicator by formula (4). The structure of separated waste has growing tendency.

The share of separated waste in the total amount of municipal waste increased and was at the level of 12 to $55 \%$ from municipal waste. This increasing is positive benefit of implemented coupon system in municipalities. The value of municipal waste creates also the item of separated waste, so it is important to

Table 5. Statistical analysis of separated waste.

\begin{tabular}{|c|c|c|c|c|c|c|c|}
\hline Municipality & $\mathrm{A} / 2017$ & $\mathrm{~A} / 2018$ & $\mathrm{~A} / 2019$ & $\mathrm{AD} 19 / 18$ & $\mathrm{AD} 18 / 17$ & $\mathrm{I} 19 / 18$ & $\mathrm{I} 18 / 17$ \\
\hline Dedinky & 52.7 & 34.7 & 66.9 & 7943.34 & -4428.00 & 1.9 & 0.7 \\
\hline Rudno nad Hronom & 21.0 & 22.0 & 31.0 & 4779.00 & 531.00 & 1.4 & 1.0 \\
\hline Pucov & 106.0 & 95.0 & 97.0 & 1720.00 & -9460.00 & 1.0 & 0.9 \\
\hline Párnica & 41.0 & 83.0 & 97.0 & 12516.00 & 37548.00 & 1.2 & 2.0 \\
\hline Oravská Poruba & 41.0 & 52.0 & 51.0 & -1046.00 & 11506.00 & 1.0 & 1.3 \\
\hline Veličná & 45.0 & 39.0 & 54.0 & 19095.00 & -7638.00 & 1.4 & 0.9 \\
\hline Istebné & 33.0 & 37.0 & 52.0 & 20400.00 & 5440.00 & 1.4 & 1.1 \\
\hline Liesek & 23.0 & 39.0 & 49.0 & 29040.00 & 46464.00 & 1.3 & 1.7 \\
\hline
\end{tabular}

Source: own study 
Table 6. Structure of separated waste.

\begin{tabular}{|c|c|c|c|c|c|}
\hline Community & 2017 & 2018 & & 2019 & \\
\hline Dedinky & $14 \%$ & $21 \%$ & $\uparrow$ & $32 \%$ & $\uparrow$ \\
\hline Rudno nad Hronom & $12 \%$ & $13 \%$ & $\uparrow$ & $19 \%$ & $\uparrow$ \\
\hline Pucov & $55 \%$ & $49 \%$ & $\downarrow$ & $47 \%$ & $\downarrow$ \\
\hline Párnica & $17 \%$ & $28 \%$ & $\uparrow$ & $32 \%$ & $\uparrow$ \\
\hline Oravská Poruba & $23 \%$ & $28 \%$ & $\uparrow$ & $35 \%$ & $\uparrow$ \\
\hline Veličná & $29 \%$ & $29 \%$ & - & $37 \%$ & $\uparrow$ \\
\hline Istebné & $16 \%$ & $25 \%$ & $\uparrow$ & $23 \%$ & $\downarrow$ \\
\hline Liesek & $25 \%$ & $38 \%$ & $\uparrow$ & $41 \%$ & $\uparrow$ \\
\hline
\end{tabular}

Source: own study

monitor its development in selected municipalities. The share of separated waste from municipal waste in all municipalities increased, except for the municipality of Pucov, where the structure of separated waste has been decreasing since 2017, despite the established coupon system for waste separation. The amount of separated waste affects the amount of fees for citizens and costs for municipal waste treatment of municipalities.

By regression analysis (Fig. 5), we found the dependence of the amount of municipal waste on the number of inhabitants of the villages.

The indicator RSquare $=0.670337$ indicates not very strong dependence of variables - the amount of municipal waste and the number of inhabitants of the municipalities. The amount of municipal waste is a dependent indicator that we want to minimize. The development trend of municipal waste has a linear progressive course in the future that means increasing of municipal waste. The number of inhabitants affects at $67.03 \%$ of the generation of municipal waste and its amount. More people in municipality create more waste, but it depends on approach of inhabitants in municipalities. Differences between municipalities that have the same coupon system in place classify waste in different quantities. The village Pucov was recorded the most separated waste per 1 person $95-106 \mathrm{~kg}$ in the monitored period 2017-2019, while this village does not have the most inhabitants only 860 people. The village Liesek has the most inhabitants of number 2904 people but only 23-49 $\mathrm{kg}$ per 1 person of separated waste. The

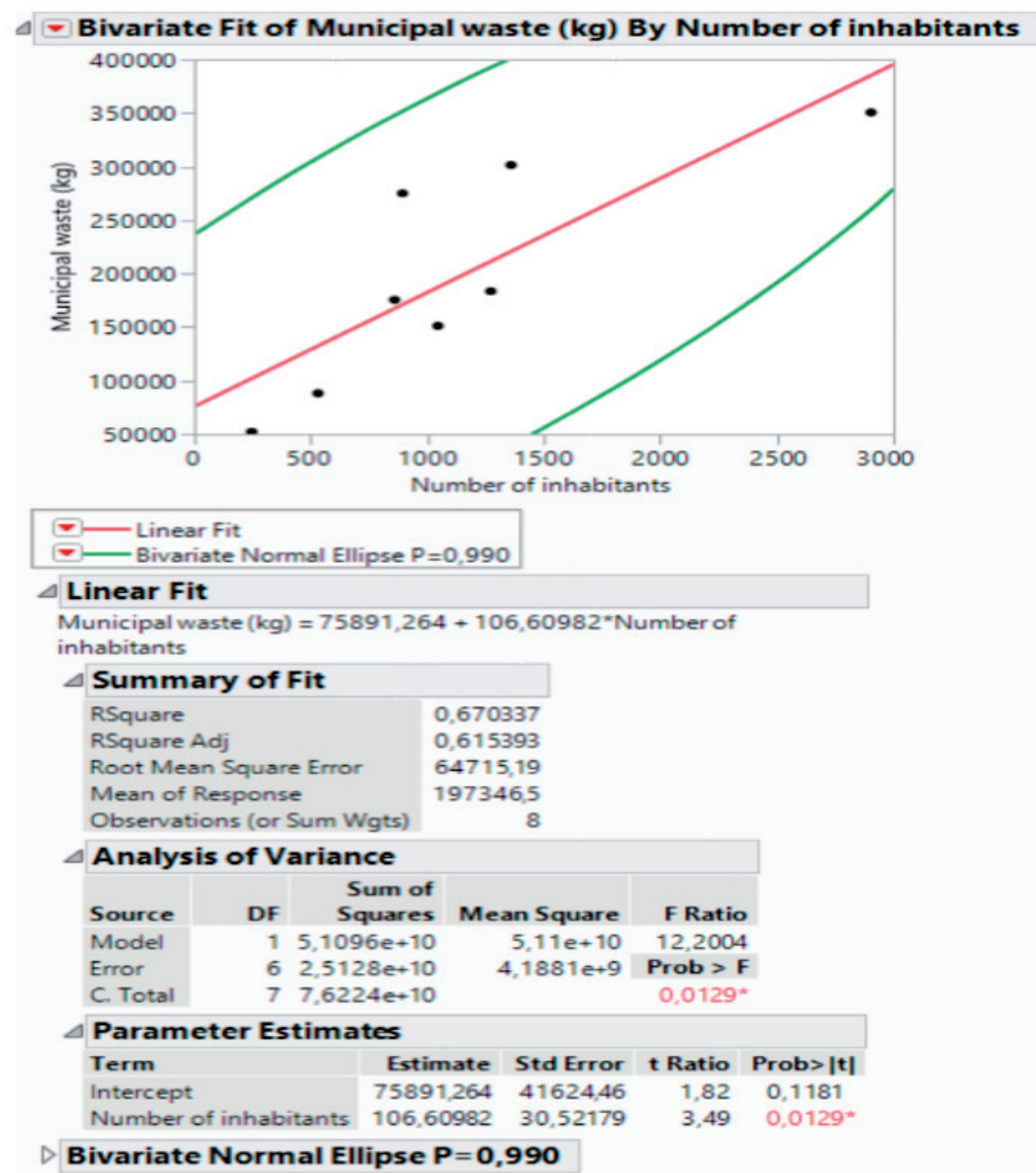

Fig. 5. Trend of municipal waste by regression analysis in municipalities in Slovakia. 


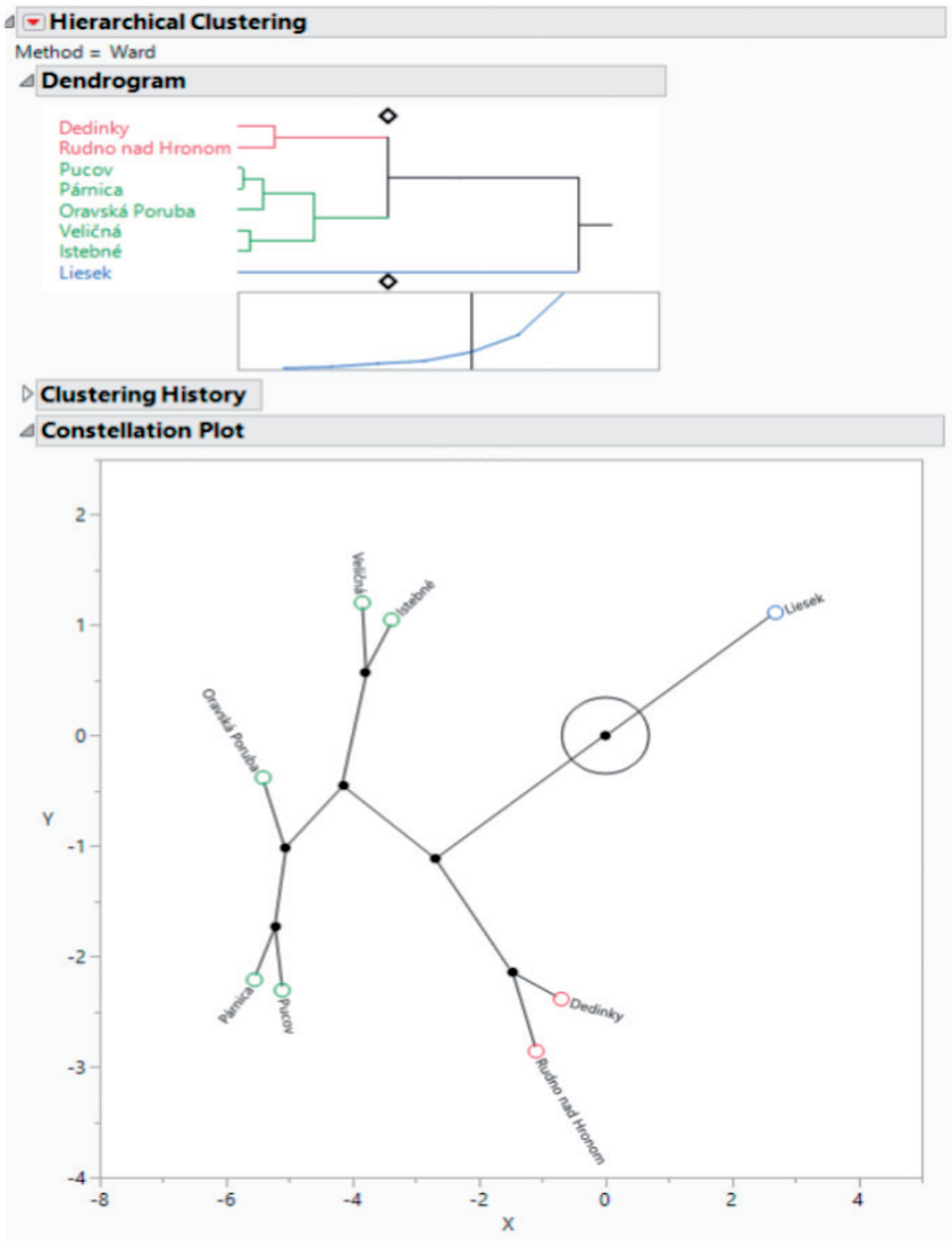

Fig. 6. Cluster analysis of municipal waste in municipalities in Slovakia.

result of waste sorting does not correlate only with the number of inhabitants but with other factors. Fewer inhabitants have sorted out more waste, which depends on the motivation and attitude of each citizen.

Based on cluster analysis (Fig. 6), we have created clusters of municipalities that separate waste in approximately equal quantities and at the same time have approximately the same number of inhabitants.

The results of the cluster analysis are three clusters with the following criteria:

$\mathbf{1}^{\text {st }}$ cluster - number of inhabitants from $0-860$ inhabitants, amount of separated waste from $8000 \mathrm{~kg}$ $30000 \mathrm{~kg}$,

$2^{\text {nd }}$ cluster - number of inhabitants from 860-2904 inhabitants, amount of separated waste from $30000 \mathrm{~kg}$ $100000 \mathrm{~kg}$,

$3^{\text {rd }}$ cluster - number of inhabitants from 2904 inhabitants, the amount of separated waste from 100000 $\mathrm{kg}$ and more.
Defined clusters can be a tool for the classification of municipalities in the sorting of municipal waste in Slovakia after the implementation of a coupon system for waste sorting.

\section{Benefits of the Coupon System in Municipalities}

The coupon system for sorting municipal waste in selected municipalities has brought environmental benefits in reducing the amount of municipal waste, increasing the amount of separated waste. The economic benefit (Table 7) was the saving of costs for the collection and processing of municipal waste for municipalities. At the same time, the benefit was the saving of financial items of individual households, because their waste fees were reduced. Overall, we can say that the introduced coupon system was beneficial for selected municipalities. This system could be legislated 
Table 7. Economic benefits in municipality Dedinky.

\begin{tabular}{|c|c|c|c|c|}
\hline Year & $\begin{array}{c}\text { Waste fees } \\
(€)\end{array}$ & $\begin{array}{c}\text { Waste } \\
(\mathrm{t})\end{array}$ & $\begin{array}{c}\text { Waste } \\
\text { reduction } \\
(\mathrm{t})\end{array}$ & $\begin{array}{c}\text { Saving } \\
\text { finance } \\
(€)\end{array}$ \\
\hline 2016 & 13723 & 100.89 & - & - \\
\hline 2017 & 6424 & 34.64 & 66.25 & 7299 \\
\hline 2018 & 4491 & 38.59 & 3.95 & 1933 \\
\hline 2019 & 4000 & 35.56 & 3.03 & 491 \\
\hline
\end{tabular}

Source: own source

by law as a possibility to reduce waste in municipalities in Slovakia.

The economic benefits of the introduced coupon system were recorded by all municipalities in reducing the costs of waste treatment, which was related to the reduction of waste. We analyzed the economic detailed benefits in a selected municipality Dedinky since the introduction of the coupon system. In the village of Dedinky, the introduction of the coupon system reduced the amount of municipal waste by 67 tons in one year, and reduced financial costs by $€ 7,300$. After the introduction of the system there is a reduction in the amount of municipal waste from 3-4 tons, and a reduction in costs from 500-2000 €. By reducing the amount of waste, the fees to the inhabitants of the municipality were reduced and the costs of the municipality for the processing of municipal waste were reduced.

\section{Discussion}

One of the possible alternatives in the area of sorting waste in municipalities is separation of waste. We can comment, very little municipalities have coupon system in area of sorting waste in Slovakia, because this coupon system is not state regulation. The waste sorting system - coupon system is focused on sorting waste components. Number of magnet coupon creates a fee of municipal waste for households. It is motivation factors for saving of financial sources and to separate waste. This system motivates citizens to separate the waste. External organization picks up the waste of full filling container with magnet code. This system brings benefits for external organization in saving times of collection, smaller quantity of waste, shorter time of waste collection - which means costs. The development of the amount of municipal waste has a growing tendency; therefore, the strategic goal of waste management of cities and municipalities is the separation of waste. The average value of separated waste has been increasing since 2017, which means a positive effect from the established coupon system for waste sorting in selected municipalities. Fewer people have sorted out more waste, which depends on the motivation and attitude of each citizen. The share of separated waste in municipalities has increased, which was the intention of the established coupon system for sorting municipal waste. The share of separated waste was increasing that is positive benefit of implemented coupon system in municipalities. By regression analysis, we found the dependence of the amount of municipal waste on the number of inhabitants of the village. The indicator $\mathrm{R}=0.6703$ indicates a not very strong dependence of variables. The development trend of municipal waste has a linear progressive course in the future that means increasing of municipal waste. The indicator RSquare indicates the population effects of the generation of municipal waste and its amount at $67.03 \%$. Defined clusters can be a tool for the classification of municipalities in the sorting of municipal waste in Slovakia after the implementation of a coupon system for waste sorting. We monitored the improvement (tab.8) on the basis of a comparative analysis of individual municipalities with an average value for the whole of Slovakia.

Municipal waste per person in the selected 8 municipalities is lower than the average municipal waste per person in Slovakia in the period 2017-2019. The amount was recorded from $392-434 \mathrm{~kg}$ per person during the period 2017-2019. Municipal waste per person in selected municipalities was 174 to $203 \mathrm{~kg}$ per person. In these municipalities decreased municipal waste the new implemented coupon system. Separated waste per person in selected municipalities is at levels 45-63 kg per person. It is a lower amount than the average in Slovakia in the period 2017-2019 at levels 42-85 kg per person. Based on this analysis, we can state an improvement in the field of waste sorting in municipalities because the amount of separated waste is coming to the average amount of Slovakia.

Table 8. Comparison of improvements at Slovakia and selected municipalities.

\begin{tabular}{|c|c|c|c|c|c|c|}
\hline Year & $\begin{array}{c}\text { Municipal waste } \\
(\mathrm{kg}) / \mathrm{person} \\
2017\end{array}$ & $\begin{array}{c}\text { Municipal waste } \\
(\mathrm{kg}) / \mathrm{person} \\
2018\end{array}$ & $\begin{array}{c}\text { Municipal waste } \\
(\mathrm{kg}) / \mathrm{person} \\
2019\end{array}$ & $\begin{array}{c}\text { Separated waste } \\
(\mathrm{kg}) / \mathrm{person} \\
2017\end{array}$ & $\begin{array}{c}\text { Separated waste } \\
(\mathrm{kg}) / \mathrm{person} \\
2018\end{array}$ & $\begin{array}{c}\text { Separated waste } \\
(\mathrm{kg}) / \mathrm{person} \\
2019\end{array}$ \\
\hline Slovakia & 392.60 & 424 & 434 & 42.51 & 60.42 & 85.88 \\
\hline $\begin{array}{c}\text { Selected } \\
\text { municipalities }\end{array}$ & 203.42 & 174.40 & 190.27 & 45.3 & 50.21 & 62.63 \\
\hline
\end{tabular}

Source: own source 


\section{Conclusions}

Waste sorting in municipalities is a key strategic goal in the field of environmental protection. Waste sorting in municipalities also has a significant impact on the economic side - the municipality's budget for payments for municipal waste, which are reduced and optimized by sorting. The introduction of the coupon system brings economic and environmental benefits to municipalities, and these are also reflected in citizens' fees for municipal waste. Waste sorting significantly reduces the amount of municipal waste deposited in landfills, eliminates the risk of landfilling, reduces the cost of removal and landfilling of unsorted waste, saves natural resources and raw materials that can be used in the recycling process, reduces the adverse effects on human health, thus contributing to a cleaner environment. Separate waste collection is the collection of separate waste components. The aim of waste sorting is to achieve recycling or reuse of sorted waste according to individual types of waste. The conclusions of the research point to an effective coupon system for waste sorting in municipalities. From the point of view of the law, it would be appropriate to propose a legislative measure for the introduction of a coupon system, ban landfill of municipal waste, provide subsidies for the implementation of new systems in practice, monitor the amount of separated waste, support domestic composting, ensure a sufficient number of containers for separated waste. The coupon system is an effective tool for sorting municipal waste and its use would be possible in all municipalities not only in Slovakia but also in EU countries. The basic precondition would be the harmonization of the Waste Law in EU and the legislative regulation of the coupon system.

\section{Acknowledgements}

This research was funded by project KEGA 009 TUKE-4/2020 "Transfer of Digitization into Education in the Study Program Business Management and Economics.

\section{Conflict of Interest}

The authors declare no conflict of interest.

\section{References}

1. WASTE LAW N.79/2015

2. TAUŠOVÁ M, MIHALÍKOVÁ E., ČULKOVÁ K., STEHLÍKOVÁ B., TAUŠ P., KUDELAS D. ŠTRBA L. Recycling of communal waste: current state and future potential for sustainable development in the EU. Sustainability, 11, (10), 1, 2019.

3. www.minzp.sk, online: https://www.minzp.sk/strategickedokumenty/
4. MALINDŽÁKOVÁ M., STRAKA M., ROSOVÁ A., KAŇUCHOVÁ M., TREBUŇA P. Modeling the process for incineration of municipal waste. Przemysl chemiczny. 94, (8), 1260, 2015.

5. STRAKA M., MALINDŽÁKOVÁ M., ROSOVÁ A., TREBUŇA $P$. The simulation model of the material flow of municipal waste recovery. Przemysł Chemiczny. 95, (4), 773, 2016.

6. TAUŠOVÁ M., MIHALÍKOVÁ E., ČULKOVÁ K., STEHLÍKOVÁ B., TAUŠ P., KUDELAS D. ŠTRBA L., DOMARACKÁ L. Analysis of Municipal waste development and management in self-governing regions of Slovakia. Sustainability, 12, (14), 1, 2020.

7. ABU-QUDAIS M., ABU-QDAIS H.A. Energy content of municipal solid waste in Jordan and its potential utilization. Energy conversion and Management. 41 (9), 983, 2000.

8. ADHIKARI B.K, TREMIER A., MARTINEZ J. ET.AL. Home and community composting for onsite treatment of urban organic waste: perspective for Europe and Canada. Waste management \& research. 28, (11), 1039, 2010.

9. ALAMGIR M., AHSAN A. Municipal solid waste and recovery potential: Bangladesh perspective. Iranian Journal of Environmental Health Science \& Engineering. 4 (2), 67, 2007.

10. BUMLEY S.J. A review of municipal solid waste composition in the United Kingdom. Waste management. 27 (10), 1274, 2007.

11. STRAKA M., ROSOVÁ A., MALINDŽÁKOVÁ M., KHOURI S., ČULKOVÁ K. Evaluating the Waste Incineration Process for Sustainable Development through Modelling, Logistics, and Simulation. Polish Journal of Environmental Studies. 27 (6), 2739, 2018.

12. BEL G., WARNER MILDRED E. Inter-municipal cooperation and costs: expectations and evidence. Public Administration. 93 (1), 52, 2015.

13. BOONROD K., TOWPRAYOON S., BONNET S., TRIPETCHKUL S. Enhancing organic waste separation at the source behavior: A case study of the application of motivation mechanisms in communities in Thailand. Resources conservation and recycling. 95, 77, 2015.

14. HWANG H.Y., KIM S.H., KIM M.S., PARK S.J., CHANG H.L. Co-composting of chicken manure with organic wastes: characterization of gases emissions and compost quality. Applied biological chemistry. 63 (1), 1, 2020.

15. BRAUWEILER H.CH., SHOKOLA V., MARKOVA O. Economic and legal mechanisms of waste management in Ukraine. Marketing and Management of innovation. 2, 359, 2017.

16. BUCCIOL A., MONTINARI N., PIOVESAN M. Do not trash the incentive. Monetary incentives and waste sorting. Scandinavian journal of economics. 117 (4), 1204, 2015.

17. BUENROSTRO O., BOCCO G., CRAM S. Classification of sources of municipal solid wastes in developing countries. Resources conservation and Recycling. 32 (1), 29, 2001.

18. BAREKOVA A., TATOSOVA L., KISS V., KOVÁČOVÁ M. Composition of the Separated Green Waste in Rural and Urban Area. Journal of ecological engineering. 21 (5), 234, 2020.

19. GARDINER R., HAJEK P. Municipal waste generation, R\&D intensity, and economic growth nexus - A case of EU regions. Waste management 114, 124, 2020.

20. TONINI D., WANDL A., MEISTER K., UNCETA P.M., TAELMAN S.E., DELMAS D.S., DEWULF J., HUYGENS D. Quantitative sustainability assessment 
of household food waste management in the Amsterdam Metropolitan Area. Resources conservation and recycling journal 160, 1, 2020.

21. ARAIZA-AGUILAR J.A., ROJAS-VALENCIA M.N., AGUILAR-VERA R.A. Forecast generation model of municipal solid waste using multiple linear regression. Global journal of environmental science and management - GJESM. 6, 1, 2020.
22. STRIČÍK M., TKÁČOVÁ V. Impact from the introduction of a municipal waste management coupon system in selected municipalities. Waste journal. 8, 5, 2019.

23. BOSÁK M., TARČA A., DUGAS J., FERENCZ V., Costs of municipal waste in Slovak republic. In $18^{\text {th }}$ International Multidisciplinary Scientific GeoConferences SGEM 2018, Bulgaria, 175, 2018. 